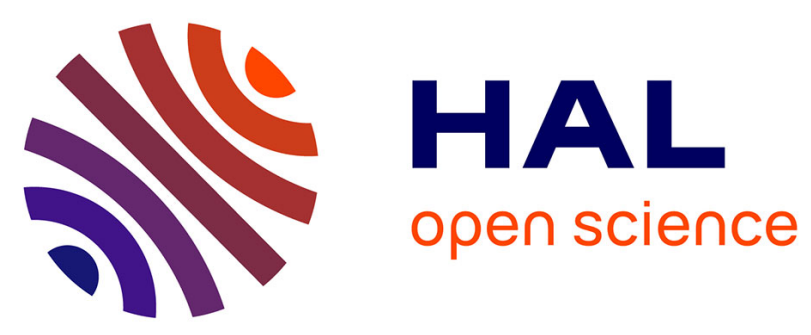

\title{
The use of accounting data to predict bank financial distress in MENA countries
}

Isabelle Distinguin, Iftekhar Hasan, Amine Tarazi

\section{To cite this version:}

Isabelle Distinguin, Iftekhar Hasan, Amine Tarazi. The use of accounting data to predict bank financial distress in MENA countries. International Journal of Banking, Accounting and Finance, 2010, 2 (4), pp.332. 10.1504/IJBAAF.2010.037154 . hal-01098715

\section{HAL Id: hal-01098715 https://hal.science/hal-01098715}

Submitted on 28 Dec 2014

HAL is a multi-disciplinary open access archive for the deposit and dissemination of scientific research documents, whether they are published or not. The documents may come from teaching and research institutions in France or abroad, or from public or private research centers.
L'archive ouverte pluridisciplinaire HAL, est destinée au dépôt et à la diffusion de documents scientifiques de niveau recherche, publiés ou non, émanant des établissements d'enseignement et de recherche français ou étrangers, des laboratoires publics ou privés. 
The Use of Accounting Data to Predict Bank Financial Distress in MENA Countries

Isabelle Distinguin, Iftekhar Hasan, and Amine Tarazi

\section{Introduction}

In the Middle Eastern and North African (MENA) region, little has been written on the prediction of bank failures. The recent financial crisis, declining bank health and government subsidization or injection of cash flow by the government sector to revive or save banking institutions from failing, have heightened interest in the role of the banking sector in the economy especially since most studies in this area pinpoint particular weaknesses in the sector which aggravated the crisis. However, most studies focus on early-warning models of banking crises (Demirgüc-Kunt and Degatriache 2000) and do not consider the prediction of bank's financial deterioration at the individual bank level.

The objectives of this paper are multiple. First, to construct an early-warning system of bank financial distress specifically designed for MENA banks. The paper also looks into the reliability and stability of early indicators depending on the size of the bank and on its balance sheet structure. Using experiences of 13 banking sectors in MENA countries as a point of study, this paper starts by building an early-warning model based on downgrades by the Fitch rating agency and a large set of accounting indicators.

Our paper proposes a framework that can be implemented for MENA banks, and which enables us to further raise two theoretical issues. First, our approach, which is applied on a wide range of MENA banks, enables to use annual frequency accounting data without imposing interpolation of these data. This point is important because for many MENA banks only yearly accounting data are available. Second, instead of focusing on bank failures or on severe financial distress, we consider the prediction of any downward change in a bank's financial health. ${ }^{1}$ Our view is that early detection of downgrades might play a major role in the implementation of prompt corrective action by regulators, and that it can do so without jeopardizing the strategies followed by bank managers. We deal with the issue of identifying

\footnotetext{
${ }^{1}$ Given regulators hardly declare bank failures but rather arrange restructuring or mergers with other healthy banks, then considering the prediction of any downward change in a bank's financial health is a good alternative to understand the extent of distress or potential failure.
} 
deterioration in banks' future financial health by considering the information contained in the changes in indicators such as financial ratios, rather than in their level. Third, we also wish to test the robustness of results in light of the modern financial intermediation theory developed by Leland and Pyle (1977), Diamond and Dybvig (1983), and Diamond (1984). These studies consider that banks and financial intermediaries are agents that play a major role in the financial system as information intermediaries. Banks collect and process information about loan customers (Diamond 1984), which implies that they possess private information. Therefore, due to banks' inherent opacity, we question the ability of accounting indicators to explain banks degradation of financial situation. We also consider the potential influence of the size of the bank on the effectiveness of accounting indicators. Indeed, we can assume that bank size affects the reliability of accounting indicators. We might suppose that accounting information is less reliable for smaller banks because accounting standards are generally less stringent for smaller banks (lower quality and lower disclosure frequency).This would be the first comprehensive attempt to better understand the banking distress in the region using a long time series data including information on banks from years as late as 2008 .

\section{Methodology}

As a first step, we test for the contributions of various accounting indicators to the prediction of bank financial distress. We then study the stability of the predictive power of early warning indicators with respect to bank size and balance sheet structure. To start off, it is necessary to establish an event that could represent a change in the financial condition of a bank. Most studies in the US conducted in this area either make use of explicit bank failures or supervisory ratings downgrades as in Curry, Elmer and Fissel (2007), Kolari et al. (2002) and Gunther, Levonian, and Moore (2001). On the other hand, studies on European banks make use of sharp downgrades (Gropp, Vesala and Vulpes 2006) as proxies for actual bank failure or downgrade announcements by private agencies ${ }^{2}$ (Distinguin, Rous and Tarazi 2006) as proxies for financial distress. Since actual bank failure is quite limited in MENA, this paper will follow Distinguin, Rous and Tarazi (2006) using downgrading announcements to represent deteriorations in the bank's financial condition. These downgrading announcements are obtained from the Fitch rating agency.

\footnotetext{
${ }^{2}$ Due to confidentiality laws in most countries, it is difficult to gain access to explicit supervisory ratings in Europe.
} 
Accounting $\mathrm{C}_{\mathrm{ji}}$ indicators are computed to estimate the probability of a downgrade. However, accounting data are available only annually. As such, the starting point for this study is December $31^{\text {st }}$ of each year - when accounting information is available. Events taking place during the following calendar year are then considered, which avoids the interpolation of missing accounting data and ensures that the information content of accounting data is not inappropriately upward biased.

For each bank in the sample, the dependent variable $\mathrm{Y}$ is equal to:

- 1 , if the bank is downgraded by Fitch with no upgrading taking place during the entire calendar year and no downgrade or upgrade during the last quarter of the preceding year;

- 0 , if the rating remains unaltered during the calendar year and;

- NA (not available), for all other cases.

The following logit model is employed to estimate the probability of a downgrade:

$$
\operatorname{Prob}\left\{Y_{i}=1\right\}=\Phi\left(\alpha+\sum_{j=1}^{J} \beta_{j} C_{j i}\right)
$$

where $\mathrm{C}_{\mathrm{ji}}$ is the $\mathrm{j}^{\text {th }}$ accounting indicator and $\Phi($.$) denotes the cumulated logistic distribution$ function. Maximum likelihood estimators of the coefficients $\left(\alpha, \beta_{j}\right)$ are used and robust Huber-White covariance matrix estimation allows for possible misspecification of the error term distribution.

The best accounting indicators are selected through a stepwise process. ${ }^{3}$

However, due to the possible existence of a size effect and a balance sheet structure effect, there is a need to test for the stability of the relationship. We also conduct estimations of the different models on restricted samples of banks and using dummy variables.

\section{Sample and Indicators}

\subsection{Sample}

\footnotetext{
${ }^{3}$ As a rule of thumb, a 10 percent level for type 1 error is retained and a Max (Min) LR statistic is used as a criterion for adding (ruling out) each potential indicator to (from) the selected set.
} 
Our sample consists of 67 commercial banks from 13 countries: Bahrain, Egypt, Israel, Jordan, Kuwait, Lebanon, Morocco, Oman, Qatar, Saudi Arabia, Tunisia, Turkey, and United Arab Emirates. These banks are rated by the Fitch rating agency.

Table 1 presents the distribution of banks by country. Information is taken from Bankscope Fitch IBCA.

Insert Table 1

Accounting data (annual financial statements) for the banks in our sample are obtained from Bankscope Fitch IBCA. Our econometric specification imposes the use of accounting data ranging from 1996 to 2007 to predict downgrades that occurred between 1998 and 2008 . Table 2 shows descriptive statistics for our sample of banks. The banks are categorized into three groups A, B, and C. The bank is classified as group A, if it is from Egypt, Lebanon, Morocco or Tunisia; then group B, if from Bahrain, Kuwait, Oman, Qatar, Saudi Arabia or United Arab Emirates, and group C, if from Israel or Turkey. It seems more prudent to group the banks into country categories as the three country groups exhibit different characteristics particularly with respect to the level of development of their financial system. The data exhibit a high level of heterogeneity, enabling us to investigate the accuracy of accounting indicators to predict downgrades for different sizes and types of institutions.

Insert Table 2

\subsection{Financial deterioration indicator}

Table 3 provides information on the downgrades used in this study. These downgrades are announced by the rating agency Fitch. Ratings information is obtained from Bankscope Fitch IBCA. Since several restrictions are applied on the construction of the binary dependent variable $\mathrm{Y}$, only a limited number of "clean" downgrades are subsequently considered in this study. For example, if several downgrades occur during the calendar year, we only consider the first one. Of the total 109 downgrades, only 52 "clean" downgrades are used for the estimations. Besides, among these 52 downgrades several happened the same day, for example a bank can be downgraded both for the Fitch Short Term and the Fitch Long Term rating at the same day. This implies that only 46 events can be used in this study. 
Table 4 provides information on the distribution of Fitch Individual, Fitch Long Term, and Fitch Short Term downgrades. We can notice that most of the ratings are in the speculative grades for debt ratings and as low as $\mathrm{C}$ or less for individual ratings.

\section{Insert Table 3 and Table 4}

\subsection{Accounting indicators}

In this study, we consider a set of accounting ratios (see Table 5) commonly used in the assessment of bank financial health. We group these ratios into the four categories of the CAEL (Capital, Asset quality, Earnings and Liquidity) rating. Previous studies in this area either consider accounting ratios in level (Curry, Elmer and Fissel 2007, Gunther, Levonian, and Moore 2001) or in variation (first order difference) (Distinguin, Rous and Tarazi 2006). In this study, as we aim to predict changes in the financial condition of the bank, it seems more appropriate to consider the changes in the values of the ratios. More importantly, our study requires equal consideration of banks regardless of their initial financial strength. More precisely, the downgrade of a sound and safe bank as compared to a modestly performing bank can only be captured by a change in the values of the ratios of this bank. Consequently, $\mathrm{C}_{\mathrm{ji}}$ is defined as the annual change in the value of the accounting ratio $\mathrm{R}_{\mathrm{ji}}$.

\section{Insert Table 5}

\section{Empirical Results}

We first consider the predictive power of accounting indicators via a stepwise process. Then, dummy variables are introduced and sub-samples are defined to capture the influence of the size of the bank and of its balance sheet structure on the effectiveness of early indicators.

As a preliminary step, univariate regressions are conducted. They are ran on the whole sample of banks without taking into account the regional sub-groups defined in 3.1. (whole sample column in Table 6), they are also ran taking into account country group differences by introducing two dummy variables GROUPA and GROUPC which are equal to one for banks belonging to the considered group (regional dummies column in Table 6) or running the regressions on the three different subgroups. 


\subsection{Simple regression results}

Table 6 shows the results for the univariate regressions on the accounting indicators for MENA banks. Results are only reported when the coefficients are at least significant at the 10 percent level.

\section{Insert Table 6}

We can notice that the results obtained with regional dummies are quite similar to those obtained without introducing these dummies. Indeed, the dummy variables are never significant in the regressions. Thus, in the following estimations we no longer take these dummies into account.

Considering the whole sample results, we can see that at least one indicator in each category (Capital, Asset quality, Earnings, and Liquidity) appears as significant. For capital adequacy indicators, those reflecting a change in hybrid capital appear significant at the 5 percent level. Two indicators of asset quality are also significant: the change in the ratio of loan loss reserves to gross loans (LLR_GL) and the change in the ratio of impaired loans to gross loans (IMPLOANS_GL). As expected, they are both positively linked with banks financial distress. Four indicators reflecting changes in the profitability/earnings ratios are also significant at least at the 5 percent level. The signs of the coefficients are all consistent with the expected negative relationship between profitability and bank financial distress and the expected positive relationship between cost or expenses and bank financial distress. The changes in the liquidity ratio NL_CSTFUND is also significant at 10 percent. But, the negative sign of the coefficient is not consistent with the expected negative relationship between liquidity and bank financial distress.

When we consider the results for the different sub-groups, we can notice that for Group A and Group B banks, at least one indicator is significant in each category. For Group $\mathrm{C}$ banks only three indicators appear as significant, two indicators corresponding to a change in the capital to risk weighted assets ratios (TCR and TIER1RATIO) and an indicator reflecting asset quality (LLP_NIR).

\subsection{Contribution of accounting indicators}


After conducting the univariate regressions and initially determining the set of indicators that are significant, a stepwise procedure is considered. Table 7 presents the results for the stepwise procedure based on the full set of accounting indicators. We run the stepwise process on the whole sample of banks and on the three sub-samples corresponding to the regional groups (Group A, Group B, and Group C) previously discussed.

\section{Insert Table 7}

The stepwise results show that, on the whole, asset quality and earnings indicators are the optimal predictors of bank financial distress. Indeed, when we consider the results obtained on the whole sample of banks, $\triangle$ COSTTOINCOME is significant at the 1 percent level. This ratio measures the costs of running the bank as a percentage of income generated before provisions. As expected, there is a negative relationship between the efficiency of the bank and the probability of a future downgrade. $\triangle$ LLP_NIR and $\triangle$ IMPLOANS_GL, both reflecting problems in bank asset quality, are, as expected, positively and significantly related to banks financial distress.

Results for Group A and Group B are quite the same as for each group both asset quality and earnings indicators are selected by the stepwise process: the change in the ratio of net interest revenue to average assets (NIR_A) and the change in the ratio of loan loss reserves to gross loans (LLR_GL) for Group A and the changes in the cost to income ratio (COSTTOINCOME) and in two ratios reflecting asset quality (IMPLOANS_GL, LLP_TA) for Group B. For Group C, one indicator reflecting capitalization appears as significant ( $\triangle E Q U E_{-}$DEPSTFUND) at the 10 percent level but its coefficient has the wrong sign. For group $\mathrm{C}$, an indicator of asset quality, the change in the ratio of loan loss provisions to net interest revenue (LLP_NIR), is also significant.

As previously mentioned, the possible existence of size and balance sheet structure effects might limit the accuracy of early indicators in the prediction process. Thus, we consider the influence of size and balance sheet structure on the effectiveness of accounting indicators by running the regressions on different sub-samples. Due to the limited number of observations available on the different regional sub-groups, in the following regressions, we do not separate banks on the basis of these sub-groups.

\subsection{Size effect}


We might suppose that the accuracy of accounting indicators to predict bank financial distress is lower for small banks. Indeed, accounting information may be less reliable for smaller banks because accounting standards are generally less stringent for them (lower quality and lower disclosure frequency). Thus, accounting indicators may be more effective for banks that have a major position in their domestic banking system.

Thus, to consider the possible existence of a size effect on the accuracy of early indicators, estimations are conducted on two sub-samples:

- Too Big To Fail banks, that is, banks with a Fitch Support rating equal to 1 or 2. This support rating indicates the likelihood of public or private support on a scale from 1 to 4; a grade of 1 (the highest) indicates the presence of an assured legal guarantee. FitchRatings Support Ratings are commonly used in the literature to identify too-big-to-fail banks operating outside the US (see Gropp, Vesala, and Vulpes 2006; and Distinguin, Rous, and Tarazi 2006).

- Non Too Big To Fail banks, that is, banks with a Fitch Support rating lower than 2.

The results obtained for the size effect are presented in Table 8 .

\section{Insert Table 8}

Considering the same indicators that are selected on the whole sample of banks, we can notice that these indicators are significant only for large banks. None of these indicators appear significant for small banks. This suggests that accounting information may be reliable only for large banks. However, this result could be due to the fact that the indicators selected by the stepwise process applied to the whole sample of banks are not the best indicators for the subsample of small banks. Therefore, we run the stepwise process on the two sub-samples of banks separately. The results, which are shown in Table 9, confirm the absence of significant indicators to predict downgrades for small banks. Indeed, the stepwise process is unable to select any significant (10 percent level) accounting indicator for small banks.

Insert Table 9 
Table 9A presents the same results using dummy variables rather than sub-samples. In Table 9B, where GDPPERCAPITA is introduced, we can notice that this variable is not significant for large banks but is significant at the 10 percent level for small banks. Table $9 \mathrm{C}$ shows the same results running the regressions on the sub-samples.

\subsection{Balance sheet structure effect}

We try to capture the effectiveness of early indicators for different balance sheet profiles. First, we consider the structure of assets via the importance of the ratio of net loans to total assets. Then, we study the impact of the structure of liabilities by considering alternatively the importance of the ratio of deposits to total assets and of the ratio of market funded liabilities to total assets. In each case, we consider the impact of the balance sheet structure (assets or liabilities) by running the regressions on two sub-samples constructed on the basis of the considered ratio: a sub-sample of banks with a high value of the ratio and a sub-sample of banks with a low value of the considered ratio. The threshold is the median value of the ratio.

\subsubsection{Structure of bank assets}

We separate banks on the basis of their loan activity.

Insert Table 10 and Table 11

Considering the same indicators that are selected on the whole sample of banks (Table 10), we can notice that they are almost all significant for the two sub-samples of banks. When we run the stepwise process separately on the two sub-samples (Table 11), we see that one indicator reflecting earnings $(\triangle \mathrm{ROE})$ appears as the best predictor of bank financial distress for banks heavily involved in loan activity whereas three different indicators are selected for banks with a lower value of the ratio of net loans to total assets.

Thus, it seems that bank asset structure does not deeply affect the accuracy of accounting indicators; accounting information is useful to predict bank financial distress of banks whatever their structure of assets. 


\subsubsection{Structure of bank liabilities}

First, we separate banks on the basis of their deposit activity.

Insert Table 12 and 13

The results obtained when we consider the indicators selected by the stepwise process ran on the whole sample of banks (Table 12) indicate that these indicators are not significant for banks focused on deposit activities, which may indicate that accounting information is only useful for banks with a relatively low deposit activity and more reliant on market debt or other sources of funding. However, when we consider the results obtained in Table 13, that is when we run the stepwise process separately on the two sub-samples, we see that the accurate indicators are different in the two sub-samples but accounting information is useful for both sub-samples.

When we consider the results obtained when we separate the banks on the basis of the ratio of market funded liabilities to total assets (Table 14 and Table 15), the conclusions remain the same.

Insert Table 14 and 15

\section{Conclusions}

The aim of this study is to first understand how the rating agencies determine banks' financial health based primarily on accounting information to predict the financial distress of MENA banks. It also tests for the presence of a too-big-to-fail effect. Results reflect the crucial role of the level and change of capital, asset quality, earnings, and liquidity ratios in improving the prediction of future distress. Additional factors that contribute to the improvement of the prediction models are the change in costs to income, change in net interest revenue to assets, and the change in ratio of loan loss reserves to gross loans. We observe that influence of factors vary across size of the banks as smaller banks are impacted by the outstanding credit and funding strategies. As MENA regulators make policies and provide guidelines for local banks on safety and soundness, learning from the style, approach, and experience of international rating agencies could be important. 


\section{References}

Curry T.J., P.J. Elmer and G.S. Fissel. 2007. "Equity Market Data, Bank Failures and Market Efficiency." Journal of Economics and Business 59:536-559.

Distinguin, I., P. Rous and A. Tarazi. 2006. "Market Discipline and the Use of Stock Market Data to Predict Bank Financial Distress." Journal of Financial Services Research 30: 151176.

Demirguc-kunt, A. and E. Degatriache. 2000. "Monitoring Banking Sector Fragility: a Multivariate Logit Approach.” The World Bank Economic Review 14(2): 287-307.

Diamond, D. W. 1984. Financial Intermediation and Delegated Monitoring. Review of Economic Studies 51(3): 393-414.

Diamond D.W and P. Dybvig. 1983. "Bank Runs, Deposit Insurance and Liquidity.” Journal of Political Economics 91:401-419.

Gropp R, J. Vesala and G. Vulpes .2006. "Equity and Bond Market Signals as Leading Indicators of Bank Fragility." Journal of Money, Credit and Banking 38(2): 399-428.

Gunther, J.W., M.E. Levonian and R.R. Moore. 2001. "Can the Stock Market Tell Bank Supervisors Anything They Don't Already Know?" Economic and Financial Review. Federal Reserve Bank of Dallas

Kolari, J., D. Glennon, H. Shin and M. Caputo. 2002. "Predicting Large US Commercial bank Failures." Journal of Economics and Business 54: 361-387.

Leland H.E. and D.H. Pyle. 1977. "Informational Asymmetries, Financial Structure, and Financial Intermediation.” Journal of Finance 32: 371-387. 
Table 1. Distribution of Banks by Country

\begin{tabular}{|l|c|}
\hline COUNTRY & NUMBER \\
\hline BAHRAIN & 6 \\
\hline EGYPT & 2 \\
\hline ISRAEL & 3 \\
\hline JORDAN & 4 \\
\hline KUWAIT & 5 \\
\hline LEBANON & 2 \\
\hline MOROCCO & 2 \\
\hline OMAN & 4 \\
\hline QATAR & 4 \\
\hline SAUDI ARABIA & 9 \\
\hline TUNISIA & 1 \\
\hline TURKEY & 16 \\
\hline UNITED ARAB EMIRATS & 9 \\
\hline TOTAL & 67 \\
\hline
\end{tabular}


Table 2. Descriptive Statistics on Summary Accounting Information for the Period 1997-2007.

Whole sample

\begin{tabular}{|c|c|c|c|c|c|}
\hline & Mean $^{2}$ & Median & $\begin{array}{c}\text { Standard } \\
\text { Deviation }^{2}\end{array}$ & Minimum & Maximum \\
\hline Total Assets (in million USD) & 12632.25 & 5976.10 & 17454.85 & $\overline{28.6}$ & 162567.40 \\
\hline Net Loans ${ }^{1} /$ Total Assets (\%) & 49.79 & 50.55 & 15.58 & 2.65 & 82.82 \\
\hline Deposits/ Total Assets (\%) & 80.20 & 82.82 & 9.76 & 0.00 & 97.65 \\
\hline $\begin{array}{l}\text { Subordinated Debt/ Total Assets } \\
(\%)\end{array}$ & 0.83 & 0 & 1.23 & 0.00 & 5.67 \\
\hline Tier 1 Ratio (\%) & 16.62 & 15.25 & 8.18 & 6.10 & 72.40 \\
\hline ROA (\%) & 1.94 & 1.97 & 2.16 & -24.12 & 13.15 \\
\hline
\end{tabular}

${ }^{1}$ Net loans are defined as gross loans less loan loss reserves.

${ }^{2}$ Each mean is calculated as $\bar{X}=\frac{1}{N T} \sum_{t=1}^{T} \sum_{j=1}^{N} X_{j t}$ where $\mathrm{N}$ is the number of banks and $\mathrm{T}$ is the number of financial reports.

Standard deviations were computed on a similar basis.

Group A:

\begin{tabular}{|c|c|c|c|c|c|}
\hline & Mean $^{2}$ & Median & $\begin{array}{c}\text { Standard } \\
\text { Deviation }^{2} \\
\end{array}$ & Minimum & Maximum \\
\hline$\overline{\text { Total Assets (in million USD) }}$ & 9218.29 & 5160.48 & 9306.60 & 874.50 & 39995.00 \\
\hline Net Loans $1 /$ Total Assets (\%) & 38.90 & 39.41 & 10.57 & 19.58 & 66.62 \\
\hline Deposits/ Total Assets (\%) & 85.33 & 86.36 & 4.07 & 73.12 & 91.88 \\
\hline Subordinated Debt/ Total Assets (\%) & 0.68 & 0.25 & 0.81 & 0.00 & 2.87 \\
\hline Tier 1 Ratio (\%) & 14.48 & 14.5 & 5.50 & 6.10 & 31.10 \\
\hline ROA (\%) & 1.19 & 1.06 & 1.40 & -0.19 & 13.01 \\
\hline
\end{tabular}

${ }^{1}$ Net loans are defined as gross loans less loan loss reserves.

${ }^{2}$ Each mean is calculated as $\bar{X}=\frac{1}{N T} \sum_{t=1}^{T} \sum_{j=1}^{N} X_{j t}$ where $\mathrm{N}$ is the number of banks and $\mathrm{T}$ is the number of financial reports.

Standard deviations were computed on a similar basis.

Group B:

\begin{tabular}{lrrrrr} 
& \multicolumn{1}{c}{ Mean } & & Standard & & \\
Deviation $^{2}$ & Minimum & Maximum \\
\hline Total Assets (in million USD) & 8897.69 & 5502.85 & 9296.30 & 239.30 & 55657.90 \\
Net Loans ${ }^{1}$ Total Assets (\%) & 51.81 & 52.26 & 14.97 & 2.65 & 82.82 \\
Deposits/ Total Assets (\%) & 80.05 & 82.28 & 7.85 & 46.70 & 94.05 \\
Subordinated Debt/ Total Assets (\%) & 0.58 & 0 & 1.12 & 0.00 & 5.67 \\
Tier 1 Ratio (\%) & 17.54 & 16.20 & 6.59 & 8.70 & 48.50 \\
ROA (\%) & 2.35 & 2.23 & 1.47 & -6.11 & 13.15 \\
\hline \hline
\end{tabular}

1 Net loans are defined as gross loans less loan loss reserves.

${ }^{2}$ Each mean is calculated as $\bar{X}=\frac{1}{N T} \sum_{t=1}^{T} \sum_{j=1}^{N} X_{j t}$ where N is the number of banks and $\mathrm{T}$ is the number of financial reports.

Standard deviations were computed on a similar basis

Group C:

\begin{tabular}{|c|c|c|c|c|c|}
\hline & Mean $^{2}$ & Median & $\begin{array}{c}\text { Standard } \\
\text { Deviation }^{2}\end{array}$ & Minimum & Maximum \\
\hline Total Assets (in million USD) & 28288.86 & 17268.10 & 30648.61 & 28.60 & 162567.40 \\
\hline Net Loans ${ }^{1} /$ Total Assets (\%) & 51.85 & 56.04 & 17.39 & 9.17 & 76.67 \\
\hline Deposits/ Total Assets (\%) & 76.50 & 80.70 & 15.56 & 0.00 & 97.65 \\
\hline Subordinated Debt/ Total Assets (\%) & 1.61 & 1.34 & 1.50 & 0.00 & 5.41 \\
\hline Tier 1 Ratio (\%) & 15.32 & 11.80 & 12.29 & 6.10 & 72.40 \\
\hline ROA (\%) & 0.97 & 1.16 & 3.87 & -24.12 & 10.75 \\
\hline
\end{tabular}

${ }^{1}$ Net loans are defined as gross loans less loan loss reserves.

${ }^{2}$ Each mean is calculated as $\bar{X}=\frac{1}{N T} \sum_{t=1}^{T} \sum_{j=1}^{N} X_{j t}$ where $\mathrm{N}$ is the number of banks and $\mathrm{T}$ is the number of financial reports.

Standard deviations were computed on a similar basis. 
Table 3. Downgrades Information

(Number of clean downgrades in parenthesis)

\begin{tabular}{|c|c|c|c|c|c|c|c|c|c|c|c|}
\hline & $\mathbf{1 9 9 8}$ & $\mathbf{1 9 9 9}$ & $\mathbf{2 0 0 0}$ & $\mathbf{2 0 0 1}$ & $\mathbf{2 0 0 2}$ & $\mathbf{2 0 0 3}$ & $\mathbf{2 0 0 4}$ & $\mathbf{2 0 0 5}$ & $\mathbf{2 0 0 6}$ & $\mathbf{2 0 0 7}$ & $\mathbf{2 0 0 8}$ \\
\hline & & & & & & & & & & & \\
\hline $\begin{array}{c}\text { Fitch } \\
\text { Individual }\end{array}$ & $3(1)$ & $1(1)$ & $1(1)$ & $10(4)$ & $11(6)$ & $3(3)$ & $2(1)$ & & $1(1)$ & & $21(11)$ \\
\hline $\begin{array}{c}\text { Fitch Long } \\
\text { Term }\end{array}$ & $2(2)$ & & & $24(11)$ & $9(3)$ & $11(2)$ & & & & & $1(0)$ \\
\hline $\begin{array}{c}\text { Fitch Short } \\
\text { Term }\end{array}$ & & & & $2(2)$ & $3(1)$ & $3(2)$ & & & & & $1(0)$ \\
\hline TOTAL & $5(3)$ & $1(1)$ & $1(1)$ & $36(17)$ & $23(10)$ & $17(7)$ & $2(1)$ & & $1(1)$ & & $23(11)$ \\
\hline
\end{tabular}


Table 4. Distribution of Downgrades

(Number of clean downgrades in parenthesis)

Fitch individual

\begin{tabular}{|l|l|l|l|l|l|l|}
\hline FROM & A/B & B & B/C & C & C/D & D \\
\hline TO & & & & & & \\
\hline B & $1(0)$ & & & & & \\
\hline B/C & & $7(4)$ & & & & \\
\hline C & & & 17 & & & \\
\hline C/D & & & & $13(8)$ & & \\
\hline D & & & $1(0)$ & & $7(2)$ & \\
\hline D/E & & & & & $4(2)$ & \\
\hline E & & & & & $1(0)$ & $1(0)$ \\
\hline F & & & & & & $1(0)$ \\
\hline
\end{tabular}

Fitch Long Term

\begin{tabular}{|l|l|l|l|l|l|l|l|l|l|l|l|l|}
\hline FROM & $\mathbf{A}+$ & A & A- & BBB+ & BBB & BBB- & BB + & BB & BB- & B+ & B & B- \\
\hline TO & & & & & & & & & & & & \\
\hline A- & $1(1)$ & $2(2)$ & & & & & & & & & & \\
\hline BBB+ & & & $3(3)$ & & & & & & & & & \\
\hline BBB & & & & $2(0)$ & & & & & & & & \\
\hline BBB- & & & & & & & & & & & & \\
\hline BB+ & & & & & & $2(1)$ & & & & & & \\
\hline BB & & & & & & & & & & & & \\
\hline BB- & & & & & & & & $2(2)$ & & & & \\
\hline B+ & & & & & & & & & $10(8)$ & & & \\
\hline B & & & & & & & & & $2(0)$ & $8(0)$ & & \\
\hline B- & & & & & & & & & & $2(0)$ & $11(1)$ & \\
\hline $\mathbf{C C C}+$ & & & & & & & & & & & & $2(0)$ \\
\hline
\end{tabular}

Fitch Short Term

\begin{tabular}{|l|l|l|l|l|}
\hline FROM & F1 & F2 & F3 & B \\
\hline TO & & & & \\
\hline F2 & $3(3)$ & & & \\
\hline F3 & & $3(1)$ & & \\
\hline B & & & $2(1)$ & \\
\hline C & & & & $1(0)$ \\
\hline
\end{tabular}


Table 5. Accounting Ratios

\begin{tabular}{|c|c|c|}
\hline CATEGORY & DEFINITION & NAME \\
\hline \multirow{13}{*}{ CAPITAL } & Capital funds/ Deposits and short term funds & CAPFUNDS_DEPSTFUND \\
\hline & Capital funds/ total liabilities & CAPFUNDS LIAB \\
\hline & Capital funds/ net loans & CAPFUNDS_NL \\
\hline & Capital funds/ total assets & CAPFUNDS_TA \\
\hline & Equity/ deposits and short term funds & EQU_DEPSTFUND \\
\hline & Equity/ total liabilities & EQU_LIAB \\
\hline & Equity/ net loans & EQU NL \\
\hline & Equity/ total assets & EQU TA \\
\hline & Subordinated debt/ capital funds & SUB_CAPFUNDS \\
\hline & Total capital ratio & TCR \\
\hline & Tier1 ratio & TIER1RATIO \\
\hline & Hybrid capital/ total liabilities & HYBRIDCAP_LIAB \\
\hline & Hybrid capital/ total assets & HYBRIDCAP TA \\
\hline \multirow{9}{*}{$\begin{array}{l}\text { ASSET } \\
\text { QUALITY }\end{array}$} & Loan loss reserves/ impaired loans & LLR_IMPLOANS \\
\hline & Impaired loans/gross loans & IMPLOANS_GL \\
\hline & Loan loss provision/ net interest revenue & LLP NIR \\
\hline & Loan loss reserve/ gross loan & LLR_GL \\
\hline & Net charge off/gross loan & NCO_GL \\
\hline & $\begin{array}{l}\text { Net charge off/ net income before loan loss } \\
\text { provision }\end{array}$ & NCO_NIBLLP \\
\hline & Loan loss provision/ total assets & LLP TA \\
\hline & Loan loss provision/gross loan & LLP_GL \\
\hline & Loan loss reserves/ total assets & LLR_TA \\
\hline \multirow{12}{*}{ EARNINGS } & Cost to income ratio & COSTTOINCOME \\
\hline & Income net of distribution/ average equity & INCNET_EQU \\
\hline & Net interest margin & NIM \\
\hline & Net interest revenue/ average assets & NIR_A \\
\hline & Non interest expenses/ average assets & NONINTEXP_A \\
\hline & Non operating items and taxes/ average assets & NONOPIT A \\
\hline & Non operating items/ net income & NONOPIT_NETINC \\
\hline & Other operating income/ average assets & OTHOPINC_A \\
\hline & Pre-tax operating income/ average assets & PRETAXOPINC_A \\
\hline & Roa & ROA \\
\hline & Roe & ROE \\
\hline & $\begin{array}{l}\text { Recurring earning power }=(\text { before tax profits }+ \\
\text { provisions for bad debts }) / \text { total assets }\end{array}$ & RECUREARNPOWER \\
\hline \multirow{5}{*}{ LIQUIDITY } & Interbank ratio & INTERBANK \\
\hline & Liquid assets/ total deposits and borrowings & LIQUASSETS TOTDEPBOR \\
\hline & Liquid assets/ customer and short term funds & LIQUASSETS CSTFUND \\
\hline & Net loans/ customer and short term funds & NL_CSTFUND \\
\hline & Net loans/ total deposits and borrowings & NL_DEPBOR \\
\hline
\end{tabular}


Table 6. Financial Deterioration and Early Indicators: Univariate Regressions

Model Specification: Prob $\left\{Y_{i}=1\right\}=\Phi\left(\alpha+\beta X_{i}\right)$

This table shows simple logit estimation results where the dependent variable is separately regressed on each explanatory variable and a constant. Group A corresponds to the sub-sample of banks that are from Egypt, Jordan, Lebanon, Morocco, or Tunisia, Group B corresponds to the sub-sample of banks that are from Bahrain, Kuwait, Oman, Qatar, Saudi Arabia or United Arab Emirates, and Group C

\begin{tabular}{|c|c|c|c|c|c|c|}
\hline & & $\begin{array}{l}\text { Whole } \\
\text { sample }\end{array}$ & $\begin{array}{l}\text { Regional } \\
\text { dummies }\end{array}$ & Group A & Group B & Group C \\
\hline \multirow[t]{8}{*}{ CAPITAL } & $\Delta$ HYBRIDCAP_LIAB & $\begin{array}{l}-3.260 * * \\
(-2.523)\end{array}$ & $\begin{array}{l}-4.154 * * * \\
(-2.977)\end{array}$ & & & \\
\hline & $\triangle$ HYBRIDCAP_TA & $\begin{array}{l}-3.260 * * \\
(-2.309)\end{array}$ & $\begin{array}{l}-4.230 * * * \\
(-2.780)\end{array}$ & & & \\
\hline & $\triangle$ EQU_DEPSTFUND & & & & $\begin{array}{l}-0.118 * * \\
(-2.085)\end{array}$ & \\
\hline & $\Delta$ EQU_LIAB & & & & $\begin{array}{l}-0.132 * * \\
(-2.146)\end{array}$ & \\
\hline & $\Delta \mathrm{EQU} \_\mathrm{TA}$ & & & & $\begin{array}{l}-0.236^{* *} \\
(-2.530)\end{array}$ & \\
\hline & $\triangle$ CAPFUNDS_NL & & & $\begin{array}{l}0.131 * \\
(1.779)\end{array}$ & & \\
\hline & $\Delta \mathrm{TCR}$ & & & & & $\begin{array}{l}0.515 * * \\
(2.052)\end{array}$ \\
\hline & $\triangle$ TIER1RATIO & & & & & $\begin{array}{l}0.283 * * \\
(2.072)\end{array}$ \\
\hline \multirow[t]{5}{*}{$\begin{array}{l}\text { ASSET } \\
\text { QUALITY }\end{array}$} & $\Delta$ LLR_GL & $\begin{array}{l}0.133 * * \\
(2.092)\end{array}$ & $\begin{array}{l}0.132 * * \\
(2.094)\end{array}$ & $\begin{array}{l}0.577 * * \\
(2.479)\end{array}$ & & \\
\hline & $\Delta$ IMPLOANS_GL & $\begin{array}{l}0.269 * * * \\
(3.167)\end{array}$ & $\begin{array}{l}0.276^{* * *} \\
(3.139)\end{array}$ & $\begin{array}{l}0.424 * * \\
(2.328)\end{array}$ & $\begin{array}{l}0.261 * * * \\
(2.618)\end{array}$ & \\
\hline & $\triangle \mathrm{LLR}$ IMPLOANS & & & & $\begin{array}{l}-0.012 * \\
(-1.689)\end{array}$ & \\
\hline & $\Delta$ LLP_NIR & & & & & $\begin{array}{l}0.114 * * * \\
(2.944)\end{array}$ \\
\hline & $\Delta$ LLP_GL & & & $\begin{array}{l}-2.661 * * * \\
(-3.046)\end{array}$ & & \\
\hline \multirow[t]{7}{*}{ EARNINGS } & $\triangle \mathrm{COSTTOINCOME}$ & $\begin{array}{l}0.069 * * * \\
(3.482)\end{array}$ & $\begin{array}{l}0.070 * * * \\
(3.554)\end{array}$ & & $\begin{array}{l}0.088 * * * \\
(3.649)\end{array}$ & \\
\hline & $\triangle \mathrm{INCNET}$ _EQU & $\begin{array}{l}-0.071 * * \\
(-2.531)\end{array}$ & $\begin{array}{l}-0.074 * * * \\
(-2.653)\end{array}$ & & $\begin{array}{l}-0.080 * * \\
(-2.528)\end{array}$ & \\
\hline & $\triangle$ NONINTEXP_A & $\begin{array}{l}0.724 * * \\
(2.222)\end{array}$ & $\begin{array}{l}0.735 * * \\
(2.323)\end{array}$ & & $\begin{array}{l}1.277 * * * \\
(2.729)\end{array}$ & \\
\hline & $\triangle \mathrm{ROE}$ & $\begin{array}{l}-0.059 * * \\
(-2.464)\end{array}$ & $\begin{array}{l}-0.060 * * * \\
(-2.601)\end{array}$ & $\begin{array}{l}-0.116^{*} \\
(-1.938)\end{array}$ & $\begin{array}{l}-0.083 * * \\
(-2.434)\end{array}$ & \\
\hline & $\Delta \mathrm{NIM}$ & & & $\begin{array}{l}-2.173 * * \\
(-2.181)\end{array}$ & & \\
\hline & $\triangle$ NONINTEXP_A & & & $\begin{array}{l}-2.633 * * \\
(-2.407)\end{array}$ & & \\
\hline & $\Delta$ NIR_A & & & $\begin{array}{l}-3.382 * * * \\
(-2.742)\end{array}$ & & \\
\hline \multirow[t]{2}{*}{ LIQUIDITY } & $\Delta \mathrm{NL} \_\mathrm{CSTFUND}$ & $\begin{array}{l}-0.043^{*} \\
(-1.800)\end{array}$ & $\begin{array}{l}-0.044^{*} \\
(-1.801)\end{array}$ & & $\begin{array}{l}-0.070 * \\
(-1.810)\end{array}$ & \\
\hline & $\triangle \mathrm{INTERBANK}$ & & & $\begin{array}{l}0.006^{*} \\
(1.790)\end{array}$ & & \\
\hline
\end{tabular}

corresponds to the sub-sample of banks that are from Israel or Turkey. For regional estimations, two dummy variables are added: GROUPA, which is equal to 1, if the bank belongs to Egypt, Jordan, Lebanon, Morocco, or Tunisia and 0, otherwise, and GROUPC, which is equal to1, if the bank belongs to Israel or Turkey. This model explains downgrades (whatever their extent) that occur in the next calendar year. Standard errors are adjusted using the Huber-White method. ***,** and * pertain to 1,5 and 10 percent level of significance, respectively. Z-Stats are in italics. The number of observations in the regional model is not equal to the sum of the number of observations of Group A, Group B, and Group C models because all data are not available for each bank, each year and each indicator. 
Table 7. Financial Deterioration and Early Indicators: Stepwise Results

Model Specification: Prob $\left\{Y_{i}=1\right\}=\Phi\left(\alpha+\sum_{j=1}^{J} \beta_{j} C_{j i}\right)$

\begin{tabular}{|c|c|c|c|c|c|}
\hline & & Whole sample & Group A & Group B & Group C \\
\hline & CONSTANT & $\begin{array}{l}-1.797 * * * \\
(-8.584)\end{array}$ & $\begin{array}{l}-2.652 * * * \\
(-3.642)\end{array}$ & $\begin{array}{l}-1.900 * * * \\
(-6.676)\end{array}$ & $\begin{array}{l}-2.081 * * * \\
(-3.819)\end{array}$ \\
\hline CAPITAL & $\triangle \mathrm{EQU}_{-}$DEPSTFUND & & & & $\begin{array}{l}0.019^{*} \\
(1.786)\end{array}$ \\
\hline \multirow[t]{2}{*}{ EARNINGS } & $\Delta$ COSTTOINCOME & $\begin{array}{l}0.083 * * * \\
(3.522)\end{array}$ & & $\begin{array}{l}0.112 * * * \\
(3.617)\end{array}$ & \\
\hline & $\Delta$ NIR_A & & $\begin{array}{l}-4.466 * * \\
(-2.552)\end{array}$ & & \\
\hline \multirow[t]{4}{*}{ ASSET QUALITY } & $\Delta$ IMPLOANS_GL & $\begin{array}{l}0.241 * * \\
(2.559)\end{array}$ & & $\begin{array}{l}0.210 * * \\
(2.491)\end{array}$ & \\
\hline & $\Delta$ LLP_NIR & $\begin{array}{l}0.030^{*} \\
(1.878)\end{array}$ & & & $\begin{array}{l}0.114 * * * \\
(2.968)\end{array}$ \\
\hline & $\Delta$ LLR_GL & & $\begin{array}{l}0.507 * * * \\
(2.851)\end{array}$ & & \\
\hline & $\Delta$ LLP_TA & & & $\begin{array}{l}1.363 * * \\
(1.970)\end{array}$ & \\
\hline McFadden $\mathrm{R}^{2}$ & & 0.142 & 0.380 & 0.199 & 0.175 \\
\hline Total Observations & & 238 & 54 & 151 & 47 \\
\hline $\begin{array}{l}\text { Number of } \\
\text { observations with } \\
\mathrm{Y}=1\end{array}$ & & 35 & 8 & 21 & 7 \\
\hline
\end{tabular}

This table shows logit estimation results where the dependent variable is regressed on a constant and the accounting indicators selected by a stepwise process. This model explains downgrades (whatever their extent) that occur in the next calendar year. Standard errors are adjusted using the Huber-White method. $* * *, * *$ and $*$ pertain to 1,5 and $10 \%$ level of significance, respectively. ZStats are in italics. 
Table 8 Too Big To Fail and Effectiveness of Early Indicators

Model Specification: Prob $\left\{Y_{i}=1\right\}=\Phi\left(\alpha+\sum_{j=1}^{J} \beta_{j} C_{j i}\right)$

\begin{tabular}{|l|l|l|l|}
\hline & & TBTF & NON TBTF \\
\hline & CONSTANT & $\begin{array}{l}-1.575^{* * *} \\
(-6.691)\end{array}$ & $\begin{array}{l}-2.477^{* * *} \\
(-5.136)\end{array}$ \\
\hline EARNINGS & ACOSTTOINCOME & $\begin{array}{l}0.113^{* * *} \\
(3.429)\end{array}$ & $\begin{array}{l}0.031 \\
(0.754)\end{array}$ \\
\hline ASSET QUALITY & DIMPLOANS_GL & $\begin{array}{l}0.278^{* *} \\
(2.430)\end{array}$ & $\begin{array}{l}0.218 \\
(1.144)\end{array}$ \\
\cline { 2 - 4 } & ALLP_NIR & $\begin{array}{l}0.051^{* *} \\
(2.434)\end{array}$ & $\begin{array}{l}-0.001 \\
(-0.030)\end{array}$ \\
\hline McFadden ${ }^{2}$ & & 0.190 & 0.061 \\
\hline Total Observations & & 169 & 69 \\
\hline Number of observations with Y=1 & & 30 & 5 \\
\hline
\end{tabular}

This table shows logit estimation results where the dependent variable is regressed on a constant and the accounting indicators selected by a stepwise process on the whole sample of banks. This model explains downgrades (whatever their extent) that occur in the next calendar year. Standard errors are adjusted using the Huber-White method. ***, ** and * pertain to 1,5 and $10 \%$ level of significance, respectively. Z-Stats are in italics. TBTF banks are those with a Fitch Support rating equal to 1 or 2 . 
Table 9. Too Big To Fail and Effectiveness of Early Indicators: New Stepwise

Model Specification: Prob $\left\{Y_{i}=1\right\}=\Phi\left(\alpha+\sum_{j=1}^{J} \beta_{j} C_{j i}\right)$

\begin{tabular}{|l|l|l|l|}
\hline & & TBTF & NON TBTF \\
\hline & CONSTANT & $\begin{array}{l}-1.575^{* * *} \\
(0.235)\end{array}$ & \\
\hline EARNINGS & ACOSTTOINCOME & $\begin{array}{l}0.113^{* * *} \\
(3.429)\end{array}$ & \\
\hline ASSET QUALITY & AIMPLOANS_GL & $\begin{array}{l}0.278^{* *} \\
(2.430)\end{array}$ & \\
\cline { 2 - 5 } & ALLP_NIR & $0.051^{* *}$ & \\
\hline McFadden ${ }^{2}$ & & $(2.434)$ & \\
\hline Total Observations & & 0.190 & \\
\hline Number of observations with Y=1 & & 169 & \\
\hline
\end{tabular}

This table shows logit estimation results where the dependent variable is regressed on a constant and the accounting indicators selected by new stepwise processes. This model explains downgrades (whatever their extent) that occur in the next calendar year. Standard errors are adjusted using the Huber-White method. ${ }^{* * *}, * *$ and $*$ pertain to 1,5 and 10 percent level of significance, respectively. Z-Stats are in italics. TBTF banks are those with a Fitch Support rating equal to 1 or 2 . 
Table 9A. Too Big To Fail and Effectiveness of Early Indicators

Model Specification: Prob $\left\{Y_{i}=1\right\}=\Phi\left(\alpha+\sum_{j=1}^{J} \beta_{j} C_{j i}+\sum_{j=1}^{J} \beta^{\prime}{ }_{j} C_{j i} * D U M_{-} T B T F\right)$

\begin{tabular}{|c|c|c|}
\hline & CONSTANT & $\begin{array}{l}-2.477 * * * \\
(-5.136)\end{array}$ \\
\hline EARNINGS & $\triangle \mathrm{COSTTOINCOME}$ & $\begin{array}{l}0.031 \\
(0.754)\end{array}$ \\
\hline \multirow[t]{6}{*}{ ASSET QUALITY } & $\triangle \mathrm{IMPLOANS}$ GL & $\begin{array}{l}0.218 \\
(1.144)\end{array}$ \\
\hline & $\Delta$ LLP_NIR & $\begin{array}{l}-0.001 \\
(-0.030)\end{array}$ \\
\hline & DUM_TBTF & $\begin{array}{l}0.902 * \\
(1.680)\end{array}$ \\
\hline & DUM_TBTF* $^{*} \Delta$ COSTTOINCOME & $\begin{array}{l}0.081 \\
(1.512)\end{array}$ \\
\hline & DUM_TBTF* $^{*} \Delta \mathrm{IMPLOANS} G \mathrm{GL}$ & $\begin{array}{l}0.059 \\
(0.267)\end{array}$ \\
\hline & DUM_TBTF* $\Delta$ LLP_NIR & $\begin{array}{l}0.052 \\
(1.313)\end{array}$ \\
\hline McFadden $\mathrm{R}^{2}$ & & 0.186 \\
\hline Total observations & & 238 \\
\hline Number of observations with $\mathrm{Y}=1$ & & 35 \\
\hline Risk level to reject $\beta_{1}+\beta_{1}^{\prime}=0$ & & $3.29 \%$ \\
\hline Risk level to reject $\beta_{2}+\beta_{2}^{\prime}=0$ & & $1.51 \%$ \\
\hline Risk level to reject $\beta_{3}+\beta_{3}^{\prime}=0$ & & $94.75 \%$ \\
\hline
\end{tabular}

This table shows logit estimation results where the dependent variable is regressed on a constant and the accounting indicators selected by a stepwise process on the whole sample of banks. This model explains downgrades (whatever their extent) that occur in the next calendar year. Standard errors are adjusted using the Huber-White method. ${ }^{* * *}, * *$ and $*$ pertain to 1,5 and 10 percent level of significance, respectively. Z-Stats are in italics. The dummy variable DUM_TBTF takes the value of 1 if the bank is TBTF and 0 otherwise. TBTF banks are those with a Fitch Support rating equal to 1 or 2 . 
Table 9B. Too Big To Fail and Effectiveness of Early Indicators

Model Specification:

Prob $\left\{Y_{i}=1\right\}=\Phi\left(\alpha+\sum_{j=1}^{J} \beta_{j} C_{j i}+\sum_{j=1}^{J} \beta^{\prime}{ }_{j} C_{j i}{ }^{*} D U M_{-} T B T F+\gamma\right.$ GDPPERCAPITA $+\gamma^{\prime}$ GDPPERCAPITA*DUM_TBTF $)$

\begin{tabular}{|c|c|c|}
\hline & CONSTANT & $\begin{array}{l}-3.284 * * * \\
(-3.612)\end{array}$ \\
\hline EARNINGS & $\triangle \mathrm{COSTTOINCOME}$ & $\begin{array}{l}-0.007 \\
(-0.147)\end{array}$ \\
\hline \multirow[t]{8}{*}{ ASSET QUALITY } & AIMPLOANS_GL & $\begin{array}{l}0.254 \\
(1.258)\end{array}$ \\
\hline & $\Delta$ LLP_NIR & $\begin{array}{l}-0.035 \\
(-0.700)\end{array}$ \\
\hline & DUM_TBTF & $\begin{array}{l}1.544 \\
(1.262)\end{array}$ \\
\hline & DUM_TBTF* $\triangle$ COSTTOINCOME & $\begin{array}{l}0.052 \\
(0.657)\end{array}$ \\
\hline & DUM_TBTF* $\triangle$ IMPLOANS_GL & $\begin{array}{l}0.033 \\
(0.135)\end{array}$ \\
\hline & DUM_TBTF* $\Delta$ LLP_NIR & $\begin{array}{l}0.065 \\
(1.179)\end{array}$ \\
\hline & GDPPERCAPITA & $\begin{array}{l}0.0002^{*} \\
(1.851)\end{array}$ \\
\hline & DUM_TBTF*GDPPERCAPITA & $\begin{array}{l}-0001 \\
(-1.625)\end{array}$ \\
\hline McFadden $\mathrm{R}^{2}$ & & 0.116 \\
\hline Total Observations & & 179 \\
\hline Number of observations with $\mathrm{Y}=1$ & & 24 \\
\hline Risk level to reject $\beta_{1}+\beta_{1}^{\prime}=0$ & & $3.36 \%$ \\
\hline Risk level to reject $\beta_{2}+\beta_{2}^{\prime}=0$ & & $47.33 \%$ \\
\hline Risk level to reject $\beta_{3}+\beta_{3}^{\prime}=0$ & & $3.89 \%$ \\
\hline Risk level to reject $\gamma+\gamma^{\prime}=0$ & & $19.48 \%$ \\
\hline
\end{tabular}

This table shows logit estimation results where the dependent variable is regressed on a constant and the accounting indicators selected by a stepwise process on the whole sample of banks. This model explains downgrades (whatever their extent) that occur in the next calendar year. Standard errors are adjusted using the Huber-White method. ***, ** and * pertain to 1,5 and 10 percent level of significance, respectively. Z-Stats are in italics. The dummy variable DUM_TBTF takes the value of 1 if the bank is TBTF and 0 otherwise. TBTF banks are those with a Fitch Support rating equal to $\overline{1}$ or 2. 
Table 9C. Too Big To Fail and Effectiveness of Early Indicators: New Stepwise

Model Specification: Prob $\left\{Y_{i}=1\right\}=\Phi\left(\alpha+\sum_{j=1}^{J} \beta_{j} C_{j i}\right)$

\begin{tabular}{|c|c|c|c|}
\hline & & TBTF & NON TBTF \\
\hline & CONSTANT & $\begin{array}{l}-1.74 * * \\
(-2.124)\end{array}$ & $\begin{array}{l}-3.284 * * * \\
(-3.612)\end{array}$ \\
\hline EARNINGS & $\triangle \mathrm{COSTTOINCOME}$ & $\begin{array}{l}0.045 \\
(0.717)\end{array}$ & $\begin{array}{l}-0.007 \\
(-0.147)\end{array}$ \\
\hline \multirow[t]{3}{*}{ ASSET QUALITY } & $\triangle$ IMPLOANS_GL & $\begin{array}{l}0.287 * * \\
(2.065)\end{array}$ & $\begin{array}{l}0.254 \\
(1.258)\end{array}$ \\
\hline & $\Delta$ LLP_NIR & $\begin{array}{l}0.030 \\
(1.296)\end{array}$ & $\begin{array}{l}-0.035 \\
(-0.700)\end{array}$ \\
\hline & GDPPERCAPITA & $\begin{array}{l}3.57 * 10^{-6} \\
(0.065)\end{array}$ & $\begin{array}{l}0.0002 * \\
(1.851)\end{array}$ \\
\hline McFadden $\mathrm{R}^{2}$ & & 0.089 & 0.181 \\
\hline Total observations & & 128 & 51 \\
\hline Number of observations with $\mathrm{Y}=1$ & & 19 & 5 \\
\hline
\end{tabular}

This table shows logit estimation results where the dependent variable is regressed on a constant and the accounting indicators selected by new stepwise processes. This model explains downgrades (whatever their extent) that occur in the next calendar year. Standard errors are adjusted using the Huber-White method. ***,** and * pertain to 1, 5 and 10 percent level of significance, respectively. Z-Stats are in italics. TBTF banks are those with a Fitch Support rating equal to 1 or 2 . 
Table 9D. Bank Size and Effectiveness of Early Indicators

Model Specification: Prob $\left\{Y_{i}=1\right\}=\Phi\left(\alpha+\sum_{j=1}^{J} \beta_{j} C_{j i}\right)$

\begin{tabular}{|c|c|c|c|}
\hline & & Large banks & Small banks \\
\hline & CONSTANT & $\begin{array}{l}-2.121 * * * \\
(-7.310)\end{array}$ & $\begin{array}{l}-1.707 * * * \\
(-5.116)\end{array}$ \\
\hline EARNINGS & $\triangle \mathrm{COSTTOINCOME}$ & $\begin{array}{l}0.110 * * * \\
(3.692)\end{array}$ & $\begin{array}{l}0.049 \\
(1.190)\end{array}$ \\
\hline \multirow[t]{2}{*}{ ASSET QUALITY } & $\triangle$ IMPLOANS_GL & $\begin{array}{l}0.009 \\
(0.069)\end{array}$ & $\begin{array}{l}0.329 * * * \\
(2.841)\end{array}$ \\
\hline & $\Delta$ LLP_NIR & $\begin{array}{l}0.051 * * \\
(2.430)\end{array}$ & $\begin{array}{l}0.017 \\
(1.123)\end{array}$ \\
\hline McFadden $\mathrm{R}^{2}$ & & 0.154 & 0.168 \\
\hline Total Observations & & 147 & 91 \\
\hline Number of observations with $\mathrm{Y}=1$ & & 20 & 15 \\
\hline
\end{tabular}

This table shows logit estimation results where the dependent variable is regressed on a constant and the accounting indicators selected by a stepwise process on the whole sample of banks. This model explains downgrades (whatever their extent) that occur in the next calendar year. Standard errors are adjusted using the Huber-White method. ***,** and * pertain to 1,5 and 10 percent level of significance, respectively. Z-Stats are in italics. Large banks are those with total assets greater than the median value that is 5160.48 million USD for banks belonging to Group A (Egypt, Jordan, Lebanon, Morocco, and Tunisia), 5502.85 million USD for banks belonging to Group B (Bahrain, Kuwait, Oman, Qatar, Saudi Arabia, and United Arab Emirates), and 17268.10 million USD for banks belonging to Group C (Israel and Turkey). 
Table 9E. Bank Size and Effectiveness of Early Indicators: New Stepwise

Model Specification: $\quad \operatorname{Prob}\left\{Y_{i}=1\right\}=\Phi\left(\alpha+\sum_{j=1}^{J} \beta_{j} C_{j i}\right)$

\begin{tabular}{|c|c|c|c|}
\hline & & Large banks & Small banks \\
\hline & CONSTANT & $\begin{array}{l}-2.101 * * * \\
(-7.480)\end{array}$ & $\begin{array}{l}-1.960 * * * \\
(-5.033)\end{array}$ \\
\hline CAPITAL & $\Delta \mathrm{EQU} \_\mathrm{NL}$ & $\begin{array}{l}0.061^{*} \\
(1.892)\end{array}$ & \\
\hline \multirow[t]{2}{*}{ EARNINGS } & $\triangle \mathrm{COSTTOINCOME}$ & $\begin{array}{l}0.114 * * * \\
(4.004)\end{array}$ & \\
\hline & $\Delta$ NIR_A & & $\begin{array}{l}-0.537^{*} \\
(-1.783)\end{array}$ \\
\hline \multirow[t]{2}{*}{ ASSET QUALITY } & $\Delta$ LLP_NIR & $\begin{array}{l}0.041 * \\
(1.901)\end{array}$ & \\
\hline & $\triangle$ IMPLOANS_GL & & $\begin{array}{l}0.411 * * * \\
(3.540)\end{array}$ \\
\hline LIQUIDITY & ALIQUASSETS_CSTFUND & & $\begin{array}{l}0.057 * * \\
(2.118)\end{array}$ \\
\hline McFadden $\mathrm{R}^{2}$ & & 0.149 & 0.203 \\
\hline Total Observations & & 161 & 92 \\
\hline Number of observations with $\mathrm{Y}=1$ & & 21 & 14 \\
\hline
\end{tabular}

This table shows logit estimation results where the dependent variable is regressed on a constant and the accounting indicators selected by new stepwise processes. This model explains downgrades (whatever their extent) that occur in the next calendar year. Standard errors are adjusted using the Huber-White method. ${ }^{* * *}, * *$ and $*$ pertain to 1,5 and 10 percent level of significance, respectively. Z-Stats are in italics. Large banks are those with total assets greater than the median value that is 5160.48 million USD for banks belonging to Group A (Egypt, Jordan, Lebanon, Morocco, and Tunisia), 5502.85 million USD for banks belonging to Group B (Bahrain, Kuwait, Oman, Qatar, Saudi Arabia, and United Arab Emirates), and 17268.10 million USD for banks belonging to Group C (Israel and Turkey). 
Table 10. Structure of Bank Assets and Effectiveness of Early Indicators

Model Specification: Prob $\left\{Y_{i}=1\right\}=\Phi\left(\alpha+\sum_{j=1}^{J} \beta_{j} C_{j i}\right)$

\begin{tabular}{|c|c|c|c|}
\hline & & $\begin{array}{l}\text { Net loans/ Total } \\
\text { assets low }\end{array}$ & $\begin{array}{l}\text { Net loans / total assets } \\
\text { high }\end{array}$ \\
\hline & CONSTANT & $\begin{array}{l}-2.083 * * * \\
(-5.911)\end{array}$ & $\begin{array}{l}-1.593 * * * \\
(-5.856)\end{array}$ \\
\hline EARNINGS & $\triangle \mathrm{COSTTOINCOME}$ & $\begin{array}{l}0.073 * * \\
(2.373)\end{array}$ & $\begin{array}{l}0.114 * * \\
(2.847)\end{array}$ \\
\hline \multirow[t]{2}{*}{ ASSET QUALITY } & AIMPLOANS_GL & $\begin{array}{l}0.332 * * \\
(2.077)\end{array}$ & $\begin{array}{l}0.169 * \\
(1.697)\end{array}$ \\
\hline & $\Delta$ LLP_NIR & $\begin{array}{l}0.021 \\
(1.041)\end{array}$ & $\begin{array}{l}0.035^{*} \\
(1.737)\end{array}$ \\
\hline McFadden $\mathrm{R}^{2}$ & & 0.226 & 0.090 \\
\hline Total Observations & & 122 & 116 \\
\hline $\begin{array}{l}\text { Number of observations } \\
\text { with } Y=1\end{array}$ & & 15 & 20 \\
\hline
\end{tabular}

This table shows logit estimation results where the dependent variable is regressed on a constant and the accounting indicators selected by a stepwise process on the whole sample of banks. This model explains downgrades (whatever their extent) that occur in the next calendar year. Standard errors are adjusted using the Huber-White method. $* * *, * *$ and $*$ pertain to 1,5 and 10 percent level of significance, respectively. Z-Stats are in italics. The ratio Net loans/ total assets is considered as low if it is lower than its median value and it is considered as high if it is greater than its median value. This median value is equal to 39.41 percent for banks belonging to Group A (Egypt, Jordan, Lebanon, Morocco, and Tunisia), 52.26 percent for banks belonging to Group B (Bahrain, Kuwait, Oman, Qatar, Saudi Arabia, and United Arab Emirates), and 56.04 percent for banks belonging to Group C (Israel and Turkey). 
Table 11. Structure of Bank Assets and Effectiveness of Early Indicators: New Stepwise

Model Specification: Prob $\left\{Y_{i}=1\right\}=\Phi\left(\alpha+\sum_{j=1}^{J} \beta_{j} C_{j i}\right)$

\begin{tabular}{|c|c|c|c|}
\hline & & $\begin{array}{l}\text { Net loans/ Total } \\
\text { assets low }\end{array}$ & $\begin{array}{l}\text { Net loans / total } \\
\text { assets high }\end{array}$ \\
\hline & CONSTANT & $\begin{array}{l}-2.121 * * * \\
(-5.794)\end{array}$ & $\begin{array}{l}-1.726 * * * \\
(-6.648)\end{array}$ \\
\hline \multirow[t]{2}{*}{ EARNINGS } & $\triangle$ COSTTOINCOME & $\begin{array}{l}0.064 * * \\
(2.342)\end{array}$ & \\
\hline & $\triangle \mathrm{ROE}$ & & $\begin{array}{l}-0.137 * * \\
(-2.529)\end{array}$ \\
\hline ASSET QUALITY & DIMPLOANS_GL & $\begin{array}{l}0.342 * * \\
(2.391)\end{array}$ & \\
\hline LIQUIDITY & $\begin{array}{l}\Delta \text { LIQUASSETS_CSTFUND } \\
\end{array}$ & $\begin{array}{l}0.025^{*} \\
(1.658)\end{array}$ & \\
\hline McFadden $\mathrm{R}^{2}$ & & 0.218 & 0.064 \\
\hline Total Observations & & 124 & 130 \\
\hline $\begin{array}{l}\text { Number of observations } \\
\text { with } Y=1\end{array}$ & & 15 & 21 \\
\hline
\end{tabular}

This table shows logit estimation results where the dependent variable is regressed on a constant and the accounting indicators selected by new stepwise processes. This model explains downgrades (whatever their extent) that occur in the next calendar year. Standard errors are adjusted using the Huber-White method. ${ }^{* * *}, * *$ and $*$ pertain to 1,5 and 10 percent level of significance, respectively. Z-Stats are in italics. The ratio Net loans/ total assets is considered as low if it is lower than its median value and it is considered as high if it is greater than its median value. This median value is equal to 39.41 percent for banks belonging to Group A (Egypt, Jordan, Lebanon, Morocco, and Tunisia), 52.26 percent for banks belonging to Group B (Bahrain, Kuwait, Oman, Qatar, Saudi Arabia, and United Arab Emirates), and 56.04 percent for banks belonging to Group C (Israel and Turkey). 
Table 12. Structure of Bank Liabilities and Effectiveness of Early Indicators

Model Specification: Prob $\left\{Y_{i}=1\right\}=\Phi\left(\alpha+\sum_{j=1}^{J} \beta_{j} C_{j i}\right)$

\begin{tabular}{|c|c|c|c|}
\hline & & $\begin{array}{l}\text { Deposits/total assets } \\
\text { low }\end{array}$ & $\begin{array}{l}\text { Deposits/ total assets } \\
\text { high }\end{array}$ \\
\hline & CONSTANT & $\begin{array}{l}-1.672 * * * \\
(-5.571)\end{array}$ & $\begin{array}{l}-1.922 * * * \\
(-6.393)\end{array}$ \\
\hline EARNINGS & $\triangle \mathrm{COSTTOINCOME}$ & $\begin{array}{l}0.093 * * * \\
(3.189)\end{array}$ & $\begin{array}{l}0.073 \\
(1.602)\end{array}$ \\
\hline \multirow[t]{2}{*}{ ASSET QUALITY } & DIMPLOANS_GL & $\begin{array}{l}0.466 * * * \\
(2.677)\end{array}$ & $\begin{array}{l}0.116 \\
(1.093)\end{array}$ \\
\hline & $\Delta$ LLP_NIR & $\begin{array}{l}0.026 \\
(0.895)\end{array}$ & $\begin{array}{l}0.033 \\
(1.531)\end{array}$ \\
\hline McFadden $\mathrm{R}^{2}$ & & 0.228 & 0.075 \\
\hline Total Observations & & 121 & 117 \\
\hline $\begin{array}{l}\text { Number of observations with } \\
Y=1\end{array}$ & & 20 & 15 \\
\hline
\end{tabular}

This table shows logit estimation results where the dependent variable is regressed on a constant and the accounting indicators selected by a stepwise process on the whole sample of banks. This model explains downgrades (whatever their extent) that occur in the next calendar year. Standard errors are adjusted using the Huber-White method. $* * *, * *$ and $*$ pertain to 1,5 and 10 percent level of significance, respectively. Z-Stats are in italics. The ratio Deposits/ total assets is considered as low if it is lower than its median value and it is considered as high if it is greater than its median value. This median value is equal to 86.36 percent for banks belonging to Group A (Egypt, Jordan, Lebanon, Morocco, and Tunisia), 82.28 percent for banks belonging to Group B (Bahrain, Kuwait, Oman, Qatar, Saudi Arabia, and United Arab Emirates), and 80.70 percent for banks belonging to Group C (Israel and Turkey). 
Table 13. Structure of Bank Liabilities and Effectiveness of Early Indicators: New

\section{Stepwise}

Model Specification: Prob $\left\{Y_{i}=1\right\}=\Phi\left(\alpha+\sum_{j=1}^{J} \beta_{j} C_{j i}\right)$

\begin{tabular}{|c|c|c|c|}
\hline & & $\begin{array}{l}\text { Deposits/ total assets } \\
\text { low }\end{array}$ & $\begin{array}{l}\text { Deposits/ total assets } \\
\text { high }\end{array}$ \\
\hline & CONSTANT & $\begin{array}{l}-1.629 * * * \\
(-5.995)\end{array}$ & $\begin{array}{l}-2.144 * * * \\
(-6.874)\end{array}$ \\
\hline CAPITAL & $\Delta \mathrm{EQU} \_\mathrm{TA}$ & $\begin{array}{l}-0.264 * * \\
(-2.232)\end{array}$ & \\
\hline \multirow[t]{2}{*}{ EARNINGS } & $\triangle O$ OTHOPINC_A & & $\begin{array}{l}-2.033 * * \\
(-2.219)\end{array}$ \\
\hline & $\Delta$ NIR_A & & $\begin{array}{l}-1.477 * * \\
(-2.098)\end{array}$ \\
\hline ASSET QUALITY & $\Delta$ LLR_GL & $\begin{array}{l}0.331 * * * \\
(2.705)\end{array}$ & \\
\hline McFadden $\mathrm{R}^{2}$ & & 0.067 & 0.073 \\
\hline Total Observations & & 114 & 124 \\
\hline $\begin{array}{l}\text { Number of observations with } \\
Y=1\end{array}$ & & 17 & 14 \\
\hline
\end{tabular}

This table shows logit estimation results where the dependent variable is regressed on a constant and the accounting indicators selected by new stepwise processes. This model explains downgrades (whatever their extent) that occur in the next calendar year. Standard errors are adjusted using the Huber-White method. ${ }^{* * *}, * *$ and $*$ pertain to 1,5 and 10 percent level of significance, respectively. Z-Stats are in italics. The ratio Deposits/ total assets is considered as low if it is lower than its median value and it is considered as high if it is greater than its median value. This median value is equal to 86.36 percent for banks belonging to Group A (Egypt, Jordan, Lebanon, Morocco, and Tunisia), 82.28 percent for banks belonging to Group B (Bahrain, Kuwait, Oman, Qatar, Saudi Arabia, and United Arab Emirates), and 80.70 percent for banks belonging to Group C (Israel and Turkey). 
Table 14. Structure of Bank Liabilities and Effectiveness of Early Indicators

Model Specification: Prob $\left\{Y_{i}=1\right\}=\Phi\left(\alpha+\sum_{j=1}^{J} \beta_{j} C_{j i}\right)$

\begin{tabular}{|c|c|c|c|}
\hline & & $\begin{array}{l}\text { Market funded } \\
\text { liabilities/ total assets } \\
\text { low }\end{array}$ & $\begin{array}{l}\text { Market funded liabilities/ } \\
\text { total assets high }\end{array}$ \\
\hline & CONSTANT & $\begin{array}{l}-1.590 * * * \\
(-5.773)\end{array}$ & $\begin{array}{l}-2.114 * * * \\
(-6.117)\end{array}$ \\
\hline EARNINGS & $\Delta$ COSTTOINCOME & $\begin{array}{l}0.027 \\
(0.713)\end{array}$ & $\begin{array}{l}0.121 * * * \\
(3.735)\end{array}$ \\
\hline \multirow[t]{2}{*}{ ASSET QUALITY } & AIMPLOANS_GL & $\begin{array}{l}0.213 * \\
(1.924)\end{array}$ & $\begin{array}{l}0.282 * \\
(1.735)\end{array}$ \\
\hline & $\Delta$ LLP_NIR & $\begin{array}{l}0.027 \\
(1.105)\end{array}$ & $\begin{array}{l}0.038^{*} \\
(1.767)\end{array}$ \\
\hline McFadden $\mathrm{R}^{2}$ & & 0.073 & 0.243 \\
\hline Total Observations & & 112 & 126 \\
\hline $\begin{array}{l}\text { Number of } \\
\text { observations with } Y=1\end{array}$ & & 17 & 18 \\
\hline
\end{tabular}

This table shows logit estimation results where the dependent variable is regressed on a constant and the accounting indicators selected by a stepwise process on the whole sample of banks. This model explains downgrades (whatever their extent) that occur in the next calendar year. Standard errors are adjusted using the Huber-White method. ${ }^{* * *}, * *$ and $*$ pertain to 1,5 and 10 percent level of significance, respectively. Z-Stats are in italics. The ratio Market funded liabilities/ total assets is considered as low if it is lower than its median value and it is considered as high if it is greater than its median value. This median value is equal to 5.84 percent for banks belonging to Group A (Egypt, Jordan, Lebanon, Morocco, and Tunisia), 4.27 percent for banks belonging to Group B (Bahrain, Kuwait, Oman, Qatar, Saudi Arabia, and United Arab Emirates), and 10.50 percent for banks belonging to Group C (Israel and Turkey). 
Table 15. Structure of Bank Liabilities and Effectiveness of Early Indicators: New

\section{Stepwise}

Model Specification: Prob $\left\{Y_{i}=1\right\}=\Phi\left(\alpha+\sum_{j=1}^{J} \beta_{j} C_{j i}\right)$

\begin{tabular}{|c|c|c|c|}
\hline & & $\begin{array}{l}\text { Market funded } \\
\text { liabilities/ total assets } \\
\text { low }\end{array}$ & $\begin{array}{l}\text { Market funded liabilities/ } \\
\text { total assets high }\end{array}$ \\
\hline & CONSTANT & $\begin{array}{l}-1.629 * * * \\
(-5.995)\end{array}$ & $\begin{array}{l}-2.114 * * * \\
(-6.117)\end{array}$ \\
\hline CAPITAL & $\Delta \mathrm{EQU} \_\mathrm{TA}$ & $\begin{array}{l}-0.264 * * \\
(-2.232)\end{array}$ & \\
\hline EARNINGS & $\triangle \mathrm{COSTTOINCOME}$ & & $\begin{array}{l}0.121 * * * \\
(3.735)\end{array}$ \\
\hline \multirow[t]{3}{*}{ ASSET QUALITY } & $\triangle \mathrm{IMPLOANS \_ GL}$ & & $\begin{array}{l}0.282^{*} \\
(1.735)\end{array}$ \\
\hline & $\Delta$ LLR_GL & $\begin{array}{l}0.331 * * * \\
(2.705)\end{array}$ & \\
\hline & $\Delta$ LLPROV_NIR & & $\begin{array}{l}0.038^{*} \\
(1.767)\end{array}$ \\
\hline McFadden $\mathrm{R}^{2}$ & & 0.067 & 0.243 \\
\hline Total Observations & & 114 & 126 \\
\hline $\begin{array}{l}\text { Number of } \\
\text { observations with } Y=1\end{array}$ & & 17 & 18 \\
\hline
\end{tabular}

This table shows logit estimation results where the dependent variable is regressed on a constant and the accounting indicators selected by new stepwise processes. This model explains downgrades (whatever their extent) that occur in the next calendar year. Standard errors are adjusted using the Huber-White method. $* * *, * *$ and $*$ pertain to 1,5 and 10 percent level of significance, respectively. Z-Stats are in italics. The ratio Market funded liabilities/ total assets is considered as low if it is lower than its median value and it is considered as high if it is greater than its median value. This median value is equal to 5.84 percent for banks belonging to Group A (Egypt, Jordan, Lebanon, Morocco, and Tunisia), 4.27 percent for banks belonging to Group B (Bahrain, Kuwait, Oman, Qatar, Saudi Arabia, and United Arab Emirates), and 10.50 percent for banks belonging to Group C (Israel and Turkey). 